\title{
Egg morphology and classification of Perlodinae (Plecoptera : Perlodidae)
}

\author{
B.P. Stark 1 \\ S.W. Szczytko 2
}

A new classification of Perlodinae (sensu Zwick 1973) is proposed in which three tribes are recognized. Arcynopterygini Ricker \& Scudder includes genera whose eggs are circular in cross section while Perlodini Klapálek and Diploperlini, new tribe, include genera whose eggs are triangular or semicircular in cross section.

Morphologie des ceufs et classification des Perlodinae (Plecoptera : Perlodidae).

Les auteurs proposent une nouvelle classification des Perlodinae (sensu Zwick 1973) et distinguent trois tribus dans cette sous-famille. Les Arcynopterygini Ricker \& Scudder comprennent les genres dont les oufs ont une section transversale circulaire tandis que les Perlodini Klapálek et la nouvelle tribu des Diploperlini renferment les genres dont les ceufs ont une section transversale triangulaire ou semi-circulaire.

Ricker's (1952) study remains as the only comprehensive survey of world Perlodidae yet three disparate classifications based largely on that study have arisen for the family (Table I). Ricker (1952) emphasized variations in male genitalia, nymphal mouthparts, mesosternal grooves and gills but interesting egg variations first noted by Needham \& Claassen (1925) and since documented by a number of workers (Baumann 1973; Berthélemy 1964; Knight et al. 1965a, b; Zwick 1972) have remained largely unexploited in the group.

This study grew out of an effort to examine eggs of all nearctic perlodid genera with scanning electron microscopy in order to evaluate generic limits within the group. When preliminary results obtained in 1979 suggested Perlodinae (sensu Zwick 1973) might include three natural groups, we enlarged the study to include all available world Perlodinae. Detailed egg descriptions resulting from this study

1. Department of Biology, Mississipi College, Clinton, Mississipi 39058, U.S.A.

2. College of Natural Resources, University of Wisconsin, Stevens Point, Wisconsin 54481, U.S.A.
Table I. Comparison of various classification schemes for the Perlodidae. Numbers of genera for Ricker \& Scudder (1975) are based, in part, on our assignments from the Zwick (1973) list.

\begin{tabular}{|l|l|c|}
\hline AUTHOR & SUBFAMILIES & $\begin{array}{c}\text { \# OF GENERA } \\
\text { (SUBGENERA) }\end{array}$ \\
\hline Ricker (1952) & Perlodinae & 4 \\
& Isogeniae & 3 \\
& Isoperlinae & 2 \\
Zwick (1973) & Perlodinae & 34 \\
& Isoperlinae & 6 \\
Ricker \& Scudder & Perlodinae & 3 \\
(1975) & Arcynopteryginae & 11 \\
& Isogeninae & 20 \\
& Isoperlinae & 6 \\
\hline
\end{tabular}

will appear in subsequent papers ; the purpose of this paper is to outline a revised classification for the family which is based on data selected from egg, nymphal and imaginal stages. 


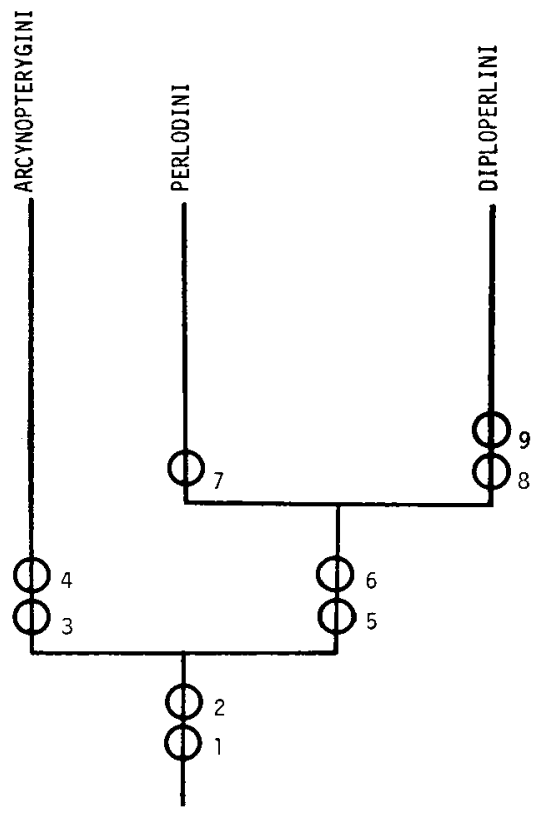

Fig. 1. Presumed phylogenetic relationships among tribes of Perlodinae. Numbers refer to apomorphies discussed in the text.

\section{1. - Classification of the Perlodidae}

We feel Perlodinae (sensu Zwick 1973) is the monophyletic sister group of Isoperlinae, hence, we follow Zwick in recognizing only these subfamilies. Apomorphies (Fig. 1) for Perlodinae include lateral stylets on the male genitalia (1) and submental gills (2) : both of these characters have been secondarily lost, independently, in several genera. Within Per. lodinae we recognize three basic lineages with tribal rank; the presumed phylogenetic relationships among these tribes is given in Fig. 1.

\section{2. - Tribe Arcynopterygini Ricker \& Scudder}

Members of this group typically exhibit eggs with circular cross sections and the collar, if present, is placed on a flattened shelf-like area often surrounded by a basal ring (Fig. 2). Nymphs usually have the mandibles deeply cleft into two major cusps with serrations along the edges of larger teeth. Both adults and nymphs are typified by well developed submental gills and several genera also have thora. cic gills. Apomorphies (Fig. 1) for the group include : (3) nymphal lacinia with ventral submarginal setal row in addition to marginal setae, and (4) slender, fingerlike male hemitergal lobes. A list of the 10 genera placed in this group is given in Table II. Protarcys Klapálek which was included tentatively by Ricker (1952) in Arcynopleryx (s.l.) has been left unplaced until specimens can be located and studied.

\section{3. - Tribe Perlodini Klapálek}

Members of this group exhibit eggs wich are triangular in cross section (Fig. 3) and males usually have the 7th sternum modified into a broad, unproduced depigmented zone. The single apomorphy (Fig. 1) identified for the group is the placement of the subapical tooth on the nymphal lacinia in a position which appears to be forward of the typical placement (7). Additionally, nymphs of most genera have a small tuft of setae set on a low knob below the subapical lacinial tooth (Frison 1942 : Hynes 1941; Stark \& Ray 1983).

Ricker (1952) and Ricker \& Scudder (1975) have maintained Diura, Filchneria, Perlodes and Perlodinella should be separated from the isogenine genera which have the male 10th tergum cleft, but in view of the fact that Filchneria, Perlodes and Diura share both egg shape and the nymphal lacinial characters with the isogenine series we feel only a single tribe is justified for these genera. A list of the 15 genera placed in Perlodini is given in Table II.

\section{4. - Tribe Diploperlini, new tribe}

Members of this group typically have turtleshaped eggs (Figs. 4, 5) and the male 7 th sternum 

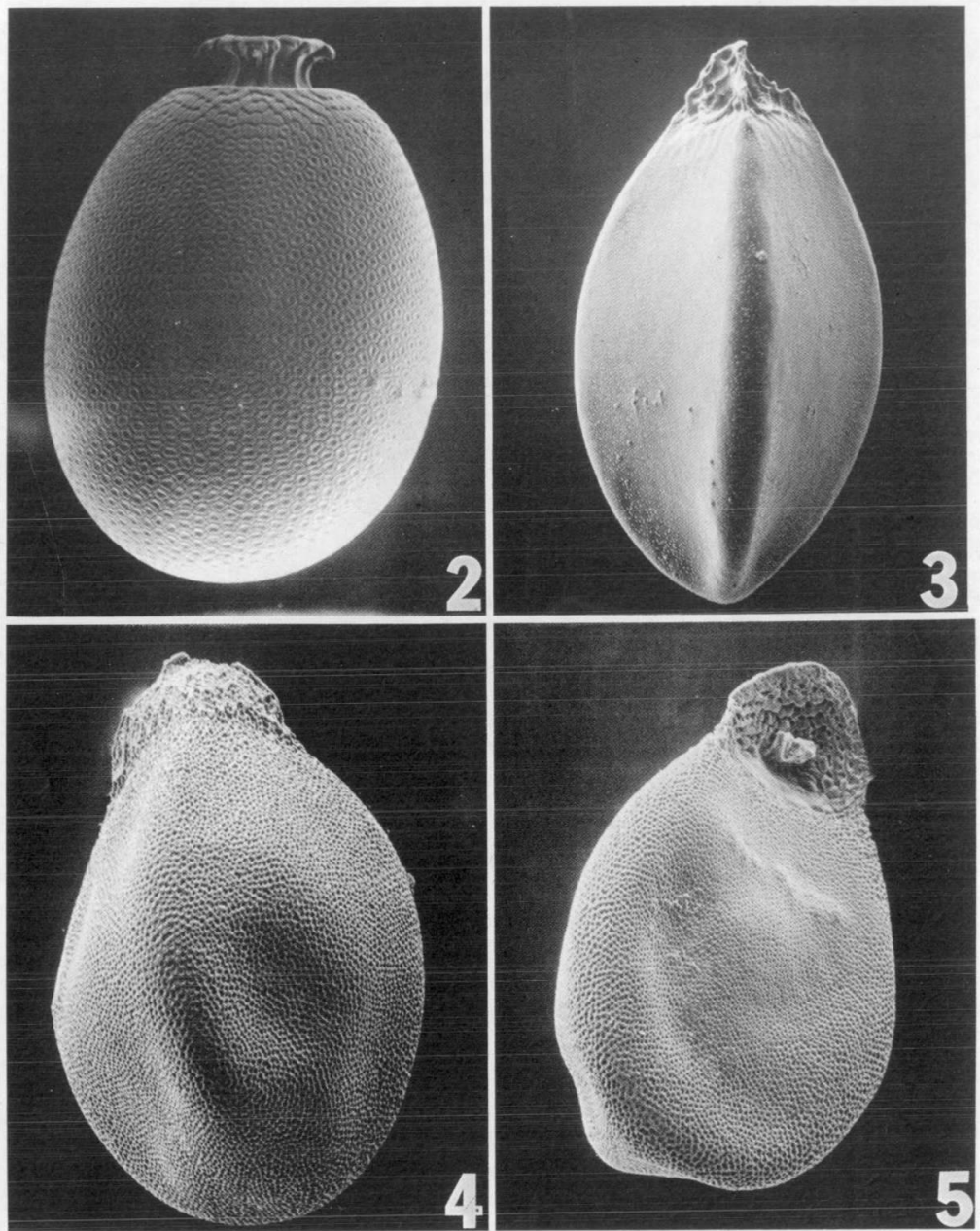

Fig. 2-5. SEM micrographs of eggs ; 2, Oroperta barbara, $208 \times: 3$, Diura knowitoni, $208 \times ; 4$. Diploperia robusta dorsal, $166 \times ; 5, D$. rabusta ventral, $166 \times$. 
Table II. Classification of Perlodinae genera by tribe. Prolarcys Klapálek not included.

\begin{tabular}{|c|c|c|}
\hline ARCYNOPTERYGINI & PERLODINI & DIPLOPERLINI \\
\hline $\begin{array}{l}\text { Arcynopteryx Klapálek } \\
\text { Frisonia Ricker } \\
\text { Megarcys Klapálek } \\
\text { Neofilchneria Zwick } \\
\text { Oroperla Needham } \\
\text { Perlinodes Needham \& Claassen } \\
\text { Pseudomegarcys Kohno } \\
\text { Setvena Illies } \\
\text { Skwala Ricker } \\
\text { Sopkalia Ricker }\end{array}$ & $\begin{array}{l}\text { Besdolus Ricker } \\
\text { Chernokrilus Ricker } \\
\text { Dictyogenus Klapálek } \\
\text { Ditura Billberg } \\
\text { Filchneria Klapálek } \\
\text { Helopicus Ricker } \\
\text { Hydroperla Frison } \\
\text { Isogenotdes Klapálek } \\
\text { Isogenus Newman } \\
\text { Malirekus Ricker } \\
\text { Oconoperla Stark \& Stewart } \\
\text { Perlodes Banks } \\
\text { Perlodinella Klapálek } \\
\text { Tadamus Ricker } \\
\text { Yugus Ricker }\end{array}$ & $\begin{array}{l}\text { Afroperlodes Miron \& Zwick } \\
\text { Bulgaroperla Rauser } \\
\text { Culuus Ricker } \\
\text { Diploperla Needham \& Claassen } \\
\text { Hemimelaena Klapálek } \\
\text { Kogotus Ricker } \\
\text { Osabenus Ricker } \\
\text { Ostrovus Ricker } \\
\text { Pictetiella Illies } \\
\text { Remenus Ricker } \\
\text { Rickera Jewett } \\
\text { Stavsolus Ricker }\end{array}$ \\
\hline
\end{tabular}

is produced into a distinct lobe which overlaps the anterior margin of sternum $8 ;$ in several genera the 8 th sternum also bears a small lobe. Apomorphies (Fig. 1) for the group include : (1) extreme reduction of setae on the nymphal lacinia, and (2) ventral position of the collar on eggs of most genera. Modifications on the male 7 th sternum (5) and of the egg shape (6) are considered as synapomorphies for Perlodini and Diploperlini (Fig. 1).

The egg of Bulgaroperla is somewhat similar to that of Oconoperla and other Perlodini but the dis. tinct lobe on male sternum 7 suggests this placement in Diploperlini. Rickera has recently been removed from Isoperlinae by Szczytko \& Stewart (1983). A list of the 12 genera placed in this tribe is given in Table II.

\section{5. - Conclusions}

The subfamily Perlodinae (sensu Zwick 1973) is a monophyletic group with three major phylogenetic lineages each characterized by distinctive eggs, nymphal lacinia and male genitalia. These lineages are, herein, given tribal rank in a revised classification. Arcynopterygini, earlier proposed by Ricker \& Scudder (1975) as a subfamily for the Arcynopteryx (sensu Ricker 1952) series, includes genera whose eggs are circular in cross section while Perlodini and Diploperlini include genera whose eggs have been modified into a roughly tretrahedral or turtle-shape respectively. The modifications may allow more efficient packing of eggs within the oviducts while opt $\mathrm{i}$ mal size is retained.

\section{Acknowledgements}

We thank the following individuals and institutions for loan of material : R.W. Baumann (Monte L. Bear Museum, Brigharn Young Univ.), O.S. Flint (United States National Museum of Natural History), P.P. Harper (Univ. of Mont real), B.C. Kondratieff (Virginia Polytechnic Inst.), J. Lattin (Oregon State Univ.), W.E. Ricker, D. Webb (Illinois Natural History Survey), G. Wiggins (Royal Ontario Museum) and P. Zwick (Max-Planck Inst. Limnologie). This study was supported in part by NSF grant \# DEB 78-12565 awar. ded to K.W. Stewart and B.P. Stark.

\section{Literature cited}

Baumann (R.W.). 1973. - Studies on Utah stoneflies (Plecoptera). Great Basin Natur., $33: 91-108$.

Berthélemy (C.). 1964. - Intérêt taxonomique des caufs chez les Perlodes Europeens (Plécopteres). Bull. Soc. Hist. Natur. Toulouse, $99: 529.537$.

Frison (T.H.). 1942 - Studies of North American Plecoptera, with special reference to the fauna of Illinois. III. Nat. Mist. Surv. Bull., 22 : 235-355.

Hynes (H.B.N.). 1941. - The taxonomy and ecology of the numphs of British Plecoptera with notes on the adults and eggs. Trans. Royal Entomol. Soc. London, 91 : 459.557.

Knight (A.W.), Nebeker (A.V.) \& Gaufin (A.R.). 1965a. - Description of the eggs of common Plecoptera of western United States. Entomol. News, 76: 105-111.

Kright (A.W.), Nebeker (A.V.) \& Gaufin (A.R.). 1965b. - Further descriptions of the eggs of Plecoptera of western United States. Entomol. News, $76: 233-239$. 
Needham (J.G.) C Clazssen (P.W.). 1925. - A monograph of the Plecoptera or stoneflies of America north of Mexico. Thomas Say Found. Entomol Soc. Amer., 2: 1-397.

Ricker (W. E). 1952. - Systematic studies in Plecoptera. Ind. Univ. Pub. Sci, 18: 1-200.

Ricker (W.E.) \& Scudder (C.G.E.). 1975. - An annotated checklist of the Plecoptera (Insecta) of British Columbia. Syesis, $8: 333$. 348.

Stark (B.P.) \& Ray (D.H.). 1983. - A revision of the genus Helopicus (Plecoptera: Perlodidae). Freshwat. Invertebr. Biol, 2 : 16-27.
Szczytko (S.W.) \& Stewart (K.W.). 1983. - Descriptions of Rickera Jewett, Calliperla Banks and two new western Nearctic /so perla species (Plecoptera). Anr. Entomol. Soc. Amer. In press. Zwick (P.). 1972. - Die Plecopteren Pictets and Burmeisters, mit Angaben über weitere Arten (Insecta). Rev. Suisse Zoot. 78 : 1123-1194.

Zwick (P.). 1973. - Insecta : Plecoptera. Phylogenetisches System und Katalog. Das Tierreich, 94. Walter de Gruyter and Co., Berlin. xxxii +465 p. 